\title{
Spectal studies on the cadmium-ion-binding properties of bovine brain S-100b protein
}

\author{
Henry DONATO, Jr., ${ }^{*}$ Rajam S. MANI and Cyril M. KAY† \\ Medical Research Council Group in Protein Structure and Function, Department of Biochemistry, University of Alberta, \\ Edmonton, Alberta, Canada T6G 2H7
}

\begin{abstract}
The effect of $\mathrm{Cd}^{2+}$ binding on bovine brain S-100b protein was studied using c.d. u.v. difference spectroscopy and fluorescence measurements. At $\mathrm{pH} 7.5$, S-100b protein binds two $\mathrm{Cd}^{2+}$ ions per monomer with a $K_{\mathrm{d}}$ value of $3 \times 10^{-5} \mathrm{M}$. Addition of $\mathrm{Cd}^{2+}$ resulted in perturbing the single tyrosine residue $\left(\mathrm{Tyr}^{17}\right)$ in the protein as indicated by u.v. difference spectroscopy and aromatic c.d. measurements. In the presence of $\mathrm{Cd}^{2+}$, the tyrosine residue moves to a more non-polar environment, since a red shift was observed in the u.v. difference spectrum. When the protein was excited at $278 \mathrm{~nm}$, the tyrosine fluorescence emission maximum was centred at $306 \mathrm{~nm} . \mathrm{Cd}^{2+}$ addition resulted in an increase in intrinsic fluorescence intensity. Fluorescence titration with $\mathrm{Cd}^{2+}$ indicated the protein binds $\mathrm{Cd}^{2+}$ with a $K_{\mathrm{d}}$ value of $3 \times 10^{-5} \mathrm{M}$. 2$p$-Toluidinylnaphthalene-6-sulphonate-labelled protein, when excited at $345 \mathrm{~nm}$, had a fluorescence emission maximum at $440 \mathrm{~nm}$. Addition of $\mathrm{Cd}^{2+}$ to labelled protein resulted in a 5 -fold increase in fluorescence intensity accompanied by a $5 \mathrm{~nm}$ blue shift in the emission maximum, suggesting that the probe, in the presence of $\mathrm{Cd}^{2+}$, moves to a hydrophobic domain. U.v. difference spectroscopic studies indicated a unique $\mathrm{Cd}^{2+}$-binding site on the protein, since $\mathrm{Cd}^{2+}$ addition yielded a large positive absorption band in the $240 \mathrm{~nm}$ region that is not found with either $\mathrm{Ca}^{2+}$ or $\mathrm{Zn}^{2+}$ ions. Similar absorption bands have been observed in Cd-protein complexes such as Cd-metallothionein [Vasak, Kagi \& Hill (1981) Biochemistry 20, 2852-2856] and also in model complexes of $\mathrm{Cd}^{2+}$ with 2-mercaptoethanol. This absorption band is believed to arise as a result of charge-transfer transitions between the thiolate and $\mathrm{Cd}^{2+}$. Of the two $\mathrm{Cd}^{2+}$-binding sites on the $\beta$-chain, one must be located at the $N$-terminal end near the single tyrosine residue, since $\mathrm{Cd}^{2+}$ and $\mathrm{Zn}^{2+}$ produced similar effects on the intrinsic protein fluorescence. The other $\mathrm{Cd}^{2+}$ site which is unique to $\mathrm{Cd}^{2+}$ must be $\mathrm{Cys}^{84}$, located at the $C$-terminal end.
\end{abstract}

\section{INTRODUCTION}

The highly acidic S-100 proteins consist of a mixture of isoforms. Dimers formed by association of the two closely related polypeptide chains, $\alpha$ and $\beta$, include S-100a $(\alpha \beta), \mathrm{S}-100 \mathrm{~b}$ $(\beta \beta)$ and S-100a $\mathrm{a}_{\mathrm{o}}(\alpha \alpha)$ (Mani \& Kay, 1987; Donato, 1986). $\mathrm{S}-100 \mathrm{~b}$ from bovine brain is a $21158 \mathrm{Da}$ homodimer which represents about $50 \%$ of the S-100 fraction from the tissue. The unusual metal-ion-binding properties of $S-100 \mathrm{~b}$ have been the subject of many studies. Amino-acid-sequence studies show that the $\beta$-chain has sequence identity with the $\mathrm{Ca}^{2+}$-binding proteins calmodulin, troponin $C$ and calbindin, and possesses an 'EF hand' $\mathrm{Ca}^{2+}$-binding site near the $C$-terminus and a 'pseudo $\mathrm{EF}$ hand' $\mathrm{Ca}^{2+}$-binding site in the $\mathrm{N}$-terminal region (Isobe \& Okuyama, 1978, 1981; Szebenyi et al., 1981). $\mathrm{Ca}^{2+}$ binding perturbs the environment around $\mathrm{Tyr}^{17}$, the single tyrosine residue, decreases intrinsic protein fluorescence intensity, reduces the $\alpha$-helical content by $6 \%$, facilitates the chemical modification of $\mathrm{Cys}^{84}$, and induces a 2-fold increase in the fluorescence intensity of 2-p-toluidenylnaphthalene-6-sulphonate (TNS), but no shift in emission maximum of the dye (Baudier \& Gérard, 1983; Baudier et al., 1986; Mani \& Kay, 1987).

There are also several $\mathrm{Zn}^{2+}$-binding sites on $\mathrm{S}-100 \mathrm{~b}$. $\mathrm{Zn}^{2+}$ binding produces perturbations of the $\mathrm{Tyr}^{17}$ environment, but in this case the intrinsic protein fluorescence intensity increases severalfold. The secondary structure of the protein is little affected by $\mathrm{Zn}^{2+}$ ions, but there is a marked exposure of a hydrophobic patch on S-100b (Baudier \& Gérard, 1983; Baudier et al., 1986; Mani \& Kay, 1987). A notable distinction between S-100b and
$\mathrm{S}-100 \mathrm{a}$ is that only $\mathrm{S}-100 \mathrm{~b}$ binds to phenyl-Sepharose in the presence of $\mathrm{Zn}^{2+}$ and is subsequently eluted with EDTA-containing buffers (Baudier et al., 1982).

The $\mathrm{Ca}^{2+}$ and $\mathrm{Zn}^{2+}$ perturbations are additive, indicating that there are separate binding sites for each ion. Metal-ion-substitution studies are often used to gain further information about metal-ion-binding sites in proteins. In this regard, $\mathrm{Cd}^{2+}$ has been used as a probe ion for both $\mathrm{Zn}^{2+}$ and $\mathrm{Ca}^{2+}$ sites in proteins in n.m.r. studies. The c.d. n.m.r. spectra of liver alcohol dehydrogenase (Bobsein \& Myers, 1981), superoxide dismutase (Bailey et al., 1980), carboxypeptidase and carbonic anhydrase (Armitage et al., 1978), where $\mathrm{Cd}^{2+}$ is bound in $\mathrm{Zn}^{2+}$ sites, have been reported. In addition, $\mathrm{Cd}^{2+}$ n.m.r. spectra for calmodulin and calbindin have been reported with $\mathrm{Cd}^{2+}$ bound in the EF hand $\mathrm{Ca}^{2+}$-binding sites (Anderson et al., 1983; Vogel et al., 1983). The above results imply that $\mathrm{Cd}^{2+}$ is a potential metal-ion probe for both the $\mathrm{Ca}^{2+}$ and $\mathrm{Zn}^{2+}$ sites of S-100b. The aim of the present study was to determine the nature of the interaction of the $\mathrm{Cd}^{2+}$ with $\mathrm{S}-100 \mathrm{~b}$ using spectroscopic methods known to respond uniquely to $\mathrm{Ca}^{2+}$ or $\mathrm{Zn}^{2+}$ binding.

\section{MATERIALS AND METHODS}

\section{Protein purification}

$\mathrm{S}-100 \mathrm{~b}$ was prepared using the procedure for purifying the $\alpha$ chain of S-100a (Leung et al., 1986). Peak IV obtained from the DEAE-Sephadex A-25 column yielded pure S-100 $\beta$-chain. S$100 \mathrm{~b}$ was renatured by extensive dialysis against $100 \mathrm{~mm}$-Tris (pH 7.5)/100 mM-KCl/15 mM-2-mercaptoethanol/2 mM-EDTA 
to remove the urea. Salt, 2-mercaptoethanol and EDTA were removed by extensive dialysis (at least four changes) against $100 \mathrm{~mm}$-Tris, pH 7.5, which was also treated with Chelex-100 resin to remove traces of bivalent cations, in particular $\mathrm{Ca}^{2+}$ and $\mathrm{Zn}^{2+}$.

\section{Spectroscopy}

U.v. absorption and u.v. difference spectra were recorded on a Perkin-Elmer Lambda 5 spectrophotometer over the wavelength range $310-220 \mathrm{~nm}$ with 1-cm-path-length cells. The spectra were measured at $25^{\circ} \mathrm{C}$ with a Lauda thermoregulator connected to the sample compartment. Portions of perturbant, namely $\mathrm{Ca}^{2+}, \mathrm{Cd}^{2+}$ or $\mathrm{Zn}^{2+}$, were added to the sample cell, and an equal volume of Chelex-100-treated water was added to the reference cell.

C.d. measurements were made on a Jasco J500C instrument fitted with a DP-500N data processor as described previously (Mani \& Kay, 1983a). A mean residue weight of 116.252 was used in calculating the molar ellipticity.

Fluorescence spectra were obtained with a Perkin-Elmer model MPF-44B spectrofluorimeter, and all measurements were made at $25^{\circ} \mathrm{C}$. The instrument was operated in the radio mode, with $6 \mathrm{~nm}$ bandwidths for excitation and emission slits. The $A_{278}$ of the sample was less than 0.1. Protein concentrations were determined from absorbance measurements by using a value of 2.4 as the absorption coefficient $A_{278}^{1 \%}$ for this protein (Mani et al., 1982).

\section{RESULTS}

The effect of $\mathrm{Cd}^{2+}$ and $\mathrm{Ca}^{2+}$ addition on the aromatic c.d. spectrum of $\mathrm{S}-100 \mathrm{~b}$ is shown in Fig. 1. The ellipticity of the protein is negative between 250 and $300 \mathrm{~nm}$. The two bands at 284 and $278 \mathrm{~nm}$ can be assigned to the single tyrosine residue at position $17 . \mathrm{Cd}^{2+}$ addition resulted in perturbation of the tyrosine residue: for example, the $[\theta]_{278}$ value decreased from -27.2 to +5.4 degrees $\cdot \mathrm{dmol}^{-1}$. In the presence of $\mathrm{Ca}^{2+}$, the $[\theta]_{278}$ value changed from -27.2 to -3.3 degrees $\mathrm{cm}^{2} \cdot \mathrm{dmol}^{-1}$. However, when both $\mathrm{Cd}^{2+}$ and $\mathrm{Ca}^{2+}$ were added to apoprotein, the observed $[\theta]_{278}$ value was +14.8 degrees $\cdot \mathrm{cm}^{2} \cdot \mathrm{dmol}^{-1}$ and was independent of the order of addition of the two metal ions. In addition to the single tyrosine residue, one or more of the seven phenylalanine residues were also affected by the presence of $\mathrm{Cd}^{2+}$, as revealed by changes in the 260-270 $\mathrm{nm}$ region. Since $\mathrm{Cd}^{2+}$ was able to induce a significant change in the $[\theta]_{278}$ value, apoprotein was titrated with $\mathrm{Cd}^{2+}$ by monitoring $[\theta]_{278}$ as a function of added $\mathrm{Cd}^{2+}$. The titration curve levelled off when $2 \mathrm{~mol}$ of $\mathrm{Cd}^{2+}$ were added/mol of $\mathrm{S}-100 \mathrm{~b}$ subunit, suggesting the presence of two $\mathrm{Cd}^{2+}$ binding sites on the $\beta$-chain of the protein (inset to Fig. 1).

In the far-u.v. region of the c.d. spectrum, addition of $4 \mathrm{~mol}$ of $\mathrm{Cd}^{2+} / \mathrm{mol}$ of $\mathrm{S}-100 \mathrm{~b}$ produced a nearly $10 \%$ decrease in $[\theta]_{222}$ compared with $5 \%$ observed with $\mathrm{Ca}^{2+}$ (Mani et al., 1982). Addition of both $\mathrm{Cd}^{2+}$ and $\mathrm{Ca}^{2+}$ to $\mathrm{S}-100 \mathrm{~b}$ caused the ellipticity at $222 \mathrm{~nm}$ to decrease from $-16800 \pm 200$ to $-14500 \pm 200$ degrees $\cdot \mathrm{cm}^{2} \cdot \mathrm{dmol}^{-1}$, independently of the order of addition of metal ions, suggesting that $\mathrm{Cd}^{2+}$ and $\mathrm{Ca}^{2+}$ are probably binding at different sites on the protein. The results obtained from the aromatic and far-u.v. c.d. studies suggest that the order of addition of metal ions to S-100b is not significant, since in both experiments the magnitude of change induced by one metal ion was not significantly influenced by the presence of the other and the observed c.d. spectra were the essentially the same.

\section{Fluorescence studies}

The intensity of the S-100b emission at $304 \mathrm{~nm}$ increased dramatically upon $\mathrm{Cd}^{2+}$ addition (Fig. 2). When the protein was titrated with $\mathrm{Cd}^{2+}$, a monophasic titration curve was obtained, indicating the existence of one class of $\mathrm{Cd}^{2+}$-binding site with a $K_{\mathrm{d}}$ value of $(3.7 \pm 0.5) \times 10^{-5} \mathrm{M}$, corresponding to the $\mathrm{Cd}^{2+}$ concentration required to induce a $50 \%$ change in the observed

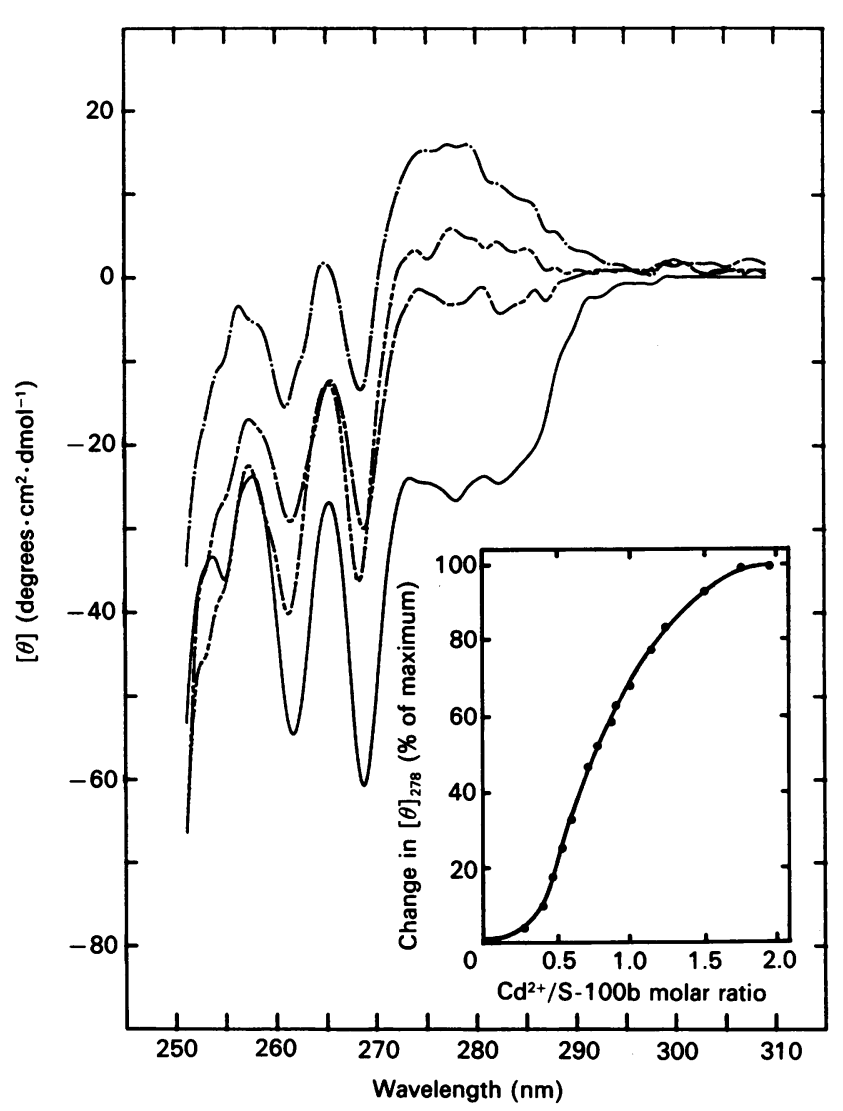

Fig. 1. Aromatic c.d. spectra of $1.34 \times 10^{-4} \mathrm{M}-\mathrm{S}-100 \mathrm{~b}$ in $0.1 \mathrm{M}-\mathrm{Tris}$, pH 7.5 $(-)$, in $0.1 \mathrm{M}-\mathrm{Tris} / 5.4 \times 10^{-4} \mathrm{M}-\mathrm{Cd}^{2+}, \mathrm{pH} 7.5(---)$, in $0.1 \mathrm{M}-$ Tris/2 mM-Ca ${ }^{2+}$, pH $7.5(--)$ and in $0.1 \mathrm{M}-\mathrm{Tris} / 5.4 \times 10^{-4} \mathrm{M}-$ $\mathrm{Cd}^{2+} / 2 \mathrm{mM}^{-\mathrm{Ca}^{2+}}$, pH 7.5 ( $\left.-\cdots \rightarrow\right)$

The inset shows the percentage change in the ellipticity at $278 \mathrm{~nm}$ as a function of the $\mathrm{Ca}^{2+} / \mathrm{S}-100 \mathrm{~b}$ molar ratio.

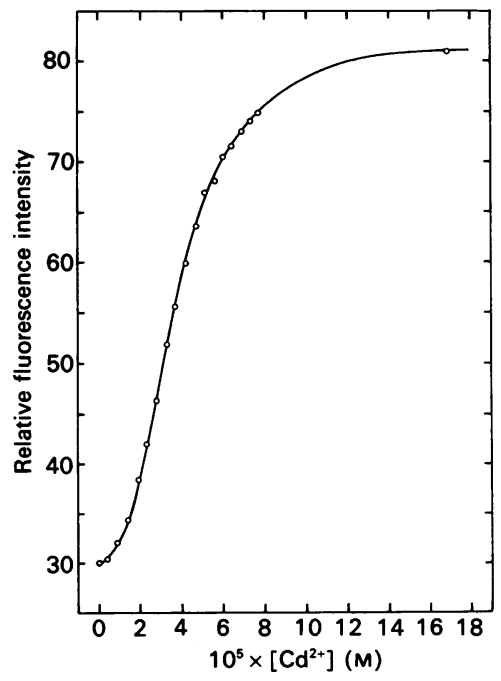

Fig. 2. Fluorimetric titration of $9.9 \times 10^{-6} \mathrm{M}-\mathrm{S}-100 \mathrm{~b}$ in $0.1 \mathrm{M}-\mathrm{Tris}, \mathrm{pH} 7.5$, with $\mathrm{Cd}^{2+}$

The excitation wavelength was $278 \mathrm{~nm}$ and the emission intensity was measured at $304 \mathrm{~nm}$. 
Table 1. Relative fluorescence intensity of S-100b in the presence of various concentrations and combinations of $\mathrm{Cd}^{2+}, \mathrm{Ca}^{2+}$ and $\mathrm{Zn}^{2+}$ ions

The values in parentheses indicate the order of addition of the metal ion. The concentration of S- $100 \mathrm{~b}$ was $9.9 \times 10^{-6} \mathrm{M}$, with an absorption of 0.05 at $278 \mathrm{~nm}$. The excitation wavelength was $278 \mathrm{~nm}$ and the emission wavelength chosen was $304 \mathrm{~nm}$.

\begin{tabular}{cccc}
\hline & & & $\begin{array}{c}\text { Fluorescence } \\
\text { intensity } \\
\text { Concn. (M) }\end{array}$ \\
\hline $\mathrm{Ca}^{2+}$ & $\mathrm{Zn}^{2+}$ & $\mathrm{Cd}^{2+}$ & $\begin{array}{c}\text { arbitrary units) } \\
\text { at } 304 \mathrm{~nm}\end{array}$ \\
\hline- & - & - & 31.4 \\
- & - & $7.4 \times 10^{-5}$ & 77.4 \\
$1.8 \times 10^{-3}(2)$ & - & $1.7 \times 10^{-4}(1)$ & 34.4 \\
$1.8 \times 10^{-3}$ & - & - & 25.7 \\
- & $6 \times 10^{-5}$ & - & 64.3 \\
- & $6 \times 10^{-5}(1)$ & $6 \times 10^{-5}(2)$ & 83.0 \\
\hline
\end{tabular}

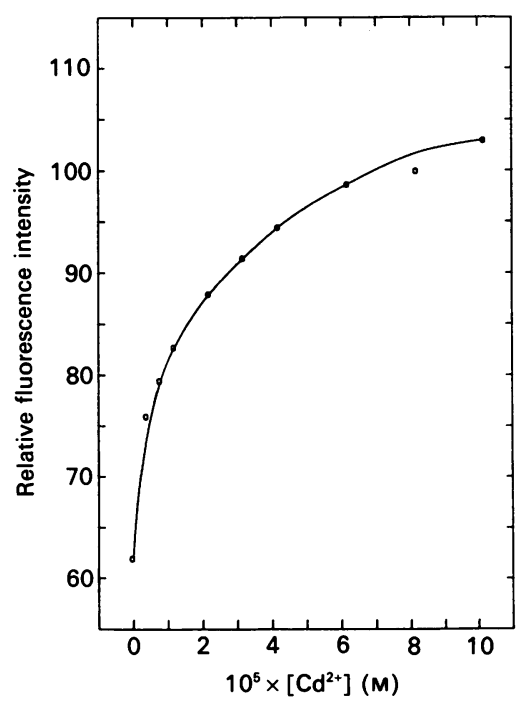

Fig. 3. Fluorimetric titration of $9.9 \times 10^{-6} \mathrm{M}-\mathrm{S}-100 \mathrm{~b}$ plus $6 \times 10^{-5} \mathrm{M}-\mathrm{Zn}^{2+}$ in $0.1 \mathrm{M}$-Tris, $\mathrm{pH} 7.5$, with $\mathrm{Cd}^{2+}$

The excitation wavelength was $278 \mathrm{~nm}$ and the emission intensity was measured at $304 \mathrm{~nm}$. fluorescence intensity. Since the protein binds two $\mathrm{Cd}^{2+}$ ions per monomer, the observed $K_{\mathrm{d}}$ value conceivably represents an average value for the two sites or, alternatively, the two sites bind $\mathrm{Cd}^{2+}$ with similar affinity with the result that it is not possible to differentiate them by this technique. The effect of $\mathrm{Cd}^{2+}, \mathrm{Ca}^{2+}$ and $\mathrm{Zn}^{2+}$ ions on the fluorescence intensity of S-100b is indicated in Table 1. When $\mathrm{Ca}^{2+}$ was added to the $\mathrm{Cd}^{2+}$-saturated protein, the observed fluorescence intensity at $304 \mathrm{~nm}$ decreased by nearly $50 \%$, thereby bringing it back to the level of the apoprotein. However, $\mathrm{Ca}^{2+}$ by itself, when added to the apoprotein, produced only an $18 \%$ decrease in fluorescence intensity, suggesting that $\mathrm{Ca}^{2+}$ has a more pronounced effect on the protein in the presence of $\mathrm{Cd}^{2+}$. Addition of $\mathrm{Cd}^{2+}$ to zinc-bound S-100b (Zn-S-100b) resulted in an additional $30 \%$ increase in fluorescence intensity. In fact, one can titrate $\mathrm{Zn}-\mathrm{S}-100 \mathrm{~b}$ with $\mathrm{Cd}^{2+}$ (Fig. 3), from which a $K_{\mathrm{d}}$ value of $2 \times 10^{-5} \mathrm{M}$ was observed for $\mathrm{Cd}^{2+}$, indicating that the affinity of the protein for $\mathrm{Cd}^{2+}$ was not influenced by the presence of $\mathrm{Zn}^{2+}$.

\section{TNS fluorescence}

The hydrophobic probe TNS fluoresces weakly in polar solvents, but its intensity becomes enhanced in apolar solvents or when bound to a hydrophobic pocket on the protein (McClure \& Edelman, 1966). TNS-labelled apoprotein, when excited at $345 \mathrm{~nm}$, had an emission maximum around $438 \pm 2 \mathrm{~nm}$. Addition of $\mathrm{Cd}^{2+}$ to labelled protein resulted in a nearly 5-fold enhancement in fluorescence intensity and this was accompanied by a $5 \mathrm{~nm}$ blue shift in the emission maximum (Table 2), implying that the probe in the presence of $\mathrm{Cd}^{2+}$ occupies a more hydrophobic environment, i.e. the protein exposes a hydrophobic region in the presence of $\mathrm{Cd}^{2+}$. From the $\mathrm{Cd}^{2+}$ titration curve generated by monitoring the fluorescence intensity at $440 \mathrm{~nm}$ as a function of $\mathrm{Cd}^{2+}$ concentration, a $K_{\mathrm{d}}$ value of $3 \times 10^{-5} \mathrm{M}$ was derived, and this corresponds to the $\mathrm{Cd}^{2+}$ concentration required to induce a $50 \%$ change in fluorescence intensity. $\mathrm{Cd}^{2+}$-induced changes in TNS fluorescence of S-100b were compared with those produced by $\mathrm{Zn}^{2+}$ and $\mathrm{Ca}^{2+}$ (Table 2). Millimolar concentrations of $\mathrm{Ca}^{2+}$ produced only a 3-fold increase in fluorescence intensity, with no noticeable change in emission maximum, whereas $\mathrm{Zn}^{2+}$ addition resulted in a 10-fold increase in fluorescence intensity, along with a $10 \mathrm{~nm}$ blue shift in the emission maximum. When $\mathrm{Cd}^{2+}$ was added to TNS-labelled S-100b protein containing $\mathrm{Zn}^{2+}(\mathrm{Zn}-\mathrm{S}-$ 100b), the emission intensity increased, whereas $\mathrm{Ca}^{2+}$ addition to TNS-labelled $\mathrm{Zn}-\mathrm{S}-100 \mathrm{~b}$ protein resulted in a decrease in the fluorescence intensity at $440 \mathrm{~nm}$. However, addition of $\mathrm{Ca}^{2+}$ to $\mathrm{Cd}^{2+}$ saturated S-100b (Cd-S-100b) protein produced a further

Table 2. Effect of $\mathrm{Cd}^{2+}, \mathrm{Ca}^{2+}$ and $\mathrm{Zn}^{2+}$ on the TNS fluorescence of S-100b in 100 mM-Tris, $\mathrm{pH} 7.5$

The values in parentheses indicate the order of addition of the metal ion. The concentration of S-100b was $9.9 \times 10^{-8} \mathrm{M}$ and that of TNS was $1.4 \times 10^{-5} \mathrm{M}$. The excitation wavelength was $325 \mathrm{~nm}$.

\begin{tabular}{|c|c|c|c|c|}
\hline \multicolumn{3}{|c|}{ Concn. (M) } & \multirow{2}{*}{$\begin{array}{c}\text { Relative fluorescence } \\
\text { intensity } \\
\text { (arbitrary units) }\end{array}$} & \multirow{2}{*}{$\begin{array}{l}\text { Emission maximum } \\
\left(\lambda_{\max .}\right)\end{array}$} \\
\hline $\mathrm{Ca}^{2+}$ & $\mathrm{Zn}^{2+}$ & $\mathrm{Cd}^{2+}$ & & \\
\hline - & - & - & 31.4 & 436 \\
\hline $2 \times 10^{-3}$ & - & - & 92.3 & 436 \\
\hline- & - & $1.2 \times 10^{-4}$ & 155.0 & 430 \\
\hline $2 \times 10^{-3}(2)$ & - & $1.2 \times 10^{-4}(1)^{*}$ & 233.0 & 430 \\
\hline- & $6 \times 10^{-5}$ & - & 297.0 & 425 \\
\hline $2 \times 10^{-3}(2)$ & $6 \times 10^{-5}(1)$ & - & 174.0 & 435 \\
\hline - & $6 \times 10^{-5}(1)$ & $6 \times 10^{-5}(2)$ & 370.0 & 430 \\
\hline $2 \times 10^{-3}(1)$ & $6 \times 10^{-5}(2)$ & - & 165.0 & 435 \\
\hline
\end{tabular}


increase in TNS fluorescence, suggesting that the $\mathrm{Ca}^{2+}$ effect on the $\mathrm{Cd}-\mathrm{S}-100 \mathrm{~b}$ protein is distinct from the $\mathrm{Zn}-\mathrm{S}-100 \mathrm{~b}$ protein.

\section{U.v. difference spectroscopy}

Fig. 4 shows the $\mathrm{Cd}^{2+}$-induced difference spectrum of S-100b. There are features around $280 \mathrm{~nm}$ region that are probably due to perturbations in the environment of the single tyrosine residue, whereas the peak at $269 \mathrm{~nm}$ and a shoulder at $263 \mathrm{~nm}$ and probably due to perturbations in the phenylalanine residues. However, the dominant feature of the difference spectrum is the presence of a large positive absorption band below $250 \mathrm{~nm}$. Fig. 5 reveals the difference spectrum in the $310-250 \mathrm{~nm}$ wavelength region at lower protein concentration. Even at this low protein concentration, one observes a pronounced shoulder at $240 \mathrm{~nm}$ with increasing absorbance at lower wavelengths. That this feature is due to $\mathrm{Cd}^{2+}$ interaction with $\mathrm{S}-100 \mathrm{~b}$ is suggested by the titration of $\mathrm{S}-100 \mathrm{~b}$ with $\mathrm{Cd}^{2+}$ while monitoring the $\Delta A_{240}$ value, which is shown in Fig. 6. The apparent dissociation constant, $K_{d}$, for this spectral change is $3.6 \times 10^{-5} \mathrm{M}$, and this value is in agreement with $K_{\mathrm{d}}$ values established by using fluorescence measurements.

\section{DISCUSSION}

The amino acid sequence of S-100b protein (Fig. 7) shows identity with the $\mathrm{Ca}^{2+}$-binding proteins belongs to the calmodulin family. The normal ' $\mathrm{EF}$ hand' $\mathrm{Ca}^{2+}$-binding site is located at the $C$-terminus between residues 61 and 72 . The second $\mathrm{Ca}^{2+}$-binding site, which operates at an elevated $\mathrm{pH}$ of 8.4 , lies between residues 18 and 31 and is referred to as the 'pseudo EF hand'. The $\beta$-subunit of $\mathrm{S}-100 \mathrm{~b}$ protein binds two $\mathrm{Ca}^{2+}$ ions with dissociation constants ranging from $10^{-5}$ to $10^{-3} \mathrm{M}$, depending on $\mathrm{pH}$, ionic strength and the presence of $\mathrm{Zn}^{2+}$ (Mani et al., 1983; Baudier et al., 1986; Baudier \& Cole, 1989). S-100b protein also possesses one high and two low-affinity zinc binding sites per subunit, with $K_{\mathrm{d}}$ values in the range of $10^{-8}$ to $10^{-6} \mathrm{M}$ (Baudier \& Gérard, 1983; Mani \& Kay, 1983b). As yet, models have not been proposed for the $\mathrm{Zn}^{2+}$-binding sites on $\mathrm{S}-100$ proteins. Nevertheless, histidine residues are known to be ubiquitous ligands for $\mathrm{Zn}^{2+}$ ions in proteins (Holmes \& Matthews, 1981). Spectroscopic studies have shown the high-affinity $\mathrm{Zn}^{2+}$-binding sites to be different from the $\mathrm{Ca}^{2+}$-binding sites and located near the single tyrosine residue, $\operatorname{Tyr}^{17}$ (Baudier \& Gérard, 1983; Mani \& Kay, 1986). The logical ligands for co-ordinating the $\mathrm{Zn}^{2+}$ ion could be the histidine residues in position 15 or 25 . Since $\mathrm{Ca}^{2+}$ antagonizes $\mathrm{Zn}^{2+}$ binding to low-affinity sites, it is conceivable that the two low-affinity $\mathrm{Zn}^{2+}$-binding sites are located at the $C$ terminal end, in close proximity to the normal 'EF hand' $\mathrm{Ca}^{2+}$ binding site (histidine residues 85 and 90 ).

$\mathrm{Cd}^{2+}$ ion is a useful and reliable probe in the study of $\mathrm{Ca}^{2+}$ binding sites in proteins (fcr a review, see Vogel et al., 1985), since $\mathrm{Ca}^{2+}$ and $\mathrm{Cd}^{2+}$ ions have the same charge and a very similar size $\left(0.097\right.$ and $0.099 \mathrm{~nm}$ respectively). However, some $\mathrm{Ca}^{2+}$. binding proteins have a different affinity for $\mathrm{Cd}^{2+}$ compared with $\mathrm{Ca}^{2+}$, and for this reason, in the present study, the interaction of $\mathrm{Cd}^{2+}$ with S-100b was carried out using spectroscopic approaches in order to compare the spectral perturbations induced by this metal ion in comparison with those produced by $\mathrm{Ca}^{2+}$ and/or $\mathrm{Zn}^{2+}$.

Addition of $\mathrm{Cd}^{2+}$ to $\mathrm{S}-100 \mathrm{~b}$ protein produced marked changes in the near- and far-u.v. c.d. spectra of the protein. Fig. 1 exhibits a positive ellipticity in the $270-290 \mathrm{~nm}$ region when 4 equiv. of $\mathrm{Cd}^{2+}$ are added to $\mathrm{S}-100 \mathrm{~b}$. Hence $\mathrm{Cd}^{2+}$, like $\mathrm{Ca}^{2+}$, alters the asymmetric environment about the single tyrosine residue in the $\beta$-chain. Subsequent addition of $\mathrm{Ca}^{2+}$ to $\mathrm{Cd}^{2+}$-containing $\mathrm{S}$ $100 \mathrm{~b}$ produced a further increase in ellipticity at $278 \mathrm{~nm}$ (from
5.4 to 14.8 degrees $\cdot \mathrm{cm}^{2} \cdot \mathrm{dmol}^{-1}$ ). Since the observed effects in the aromatic c.d. spectrum of the protein are similar and independent of the order of addition of the metal ions $\left(\mathrm{Cd}^{2+}\right.$ and $\left.\mathrm{Ca}^{2+}\right)$, one may conclude that $\mathrm{Cd}^{2+}$ and $\mathrm{Ca}^{2+}$ are possibly binding at different sites on the protein.

In the far-u.v. region of the c.d. spectrum of S-100b, addition of $\mathrm{Cd}^{2+}$ produced a nearly $10 \%$ decrease in ellipticity at $222 \mathrm{~nm}$, whereas $\mathrm{Ca}^{2+}$ addition induced only a $6 \%$ decrease in the $[\theta]_{222}$ value. $\mathrm{Zn}^{2+}$ binding to $\mathrm{S}-100 \mathrm{~b}$ resulted in minimal change (less than $1 \%$ ) in the $[\theta]_{222}$ value (Mani \& Kay, 1983a,b). Hence $\mathrm{Cd}^{2+}$-binding results in an alteration of protein secondary structure to a much larger extent than either $\mathrm{Ca}^{2+}$ or $\mathrm{Zn}^{2+}$.

The intrinsic protein fluorescence at $304 \mathrm{~nm}$, when excited at $278 \mathrm{~nm}$, decreases in intensity when $\mathrm{Ca}^{2+}$ is.bound and increases in intensity when $\mathrm{Zn}^{2+}$ is bound (Baudier et al., 1986; Mani \& Kay, 1987). It has been suggested that $\mathrm{Ca}^{2+}$ binding increases static quenching, whereas $\mathrm{Zn}^{2+}$ binding decreases static quenching of tyrosine emission. A likely candidate for the static quenching mechanism is formation of a hydrogen bond between the hydroxy group of $\mathrm{Tyr}^{17}$ and a carboxy-ion acceptor group (Baudier \& Gérard, 1983). Since $\mathrm{Cd}^{2+}$ binding resulted in an increase in the fluorescence intensity at $304 \mathrm{~nm}$, the effect of $\mathrm{Cd}^{2+}$ binding is similar to that of $\mathrm{Zn}^{2+}$ binding. Addition of $\mathrm{Ca}^{2+}$ to the $\mathrm{Cd}^{2+}$. loaded protein resulted in a dramatic decrease in fluorescence intensity. When $\mathrm{Ca}^{2+}$ was added to $\mathrm{Zn}^{2+}$-loaded protein, a decrease in the fluorescence intensity was observed and interpreted as due to $\mathrm{Ca}^{2+}$ binding at sites distinct from the $\mathrm{Zn}^{2+}$. binding sites (Baudier \& Gérard, 1983). By analogy, our results suggest that $\mathrm{Ca}^{2+}$ and $\mathrm{Cd}^{2+}$ bind independently at different sites on S-100b, in agreement with our near- and far-u.v. c.d. results. The relative fluorescence intensity of $\mathrm{Zn}^{2+}$-loaded $\mathrm{S}-100 \mathrm{~b}(\mathrm{Zn}-\mathrm{S}$ $100 \mathrm{~b}$ ) increased from 64 to 83 arbitrary units when $6 \times 10^{-5} \mathrm{M}$ $\mathrm{Cd}^{2+}$ was added to the protein. Hence the possibility exists for a $\mathrm{Cd}^{2+}$-binding site on $\mathrm{S}-100 \mathrm{~b}$, which is distinct from the $\mathrm{Zn}^{2+}$. binding site, i.e. out of the two $\mathrm{Cd}^{2+}$-binding sites at least one is unique and different from both $\mathrm{Ca}^{2+}$ - and $\mathrm{Zn}^{2+}$-binding sites on S-100b.

Although $\mathrm{Cd}^{2+}$ does not appear to bind to the $\mathrm{Ca}^{2+}$-binding sites on the apoprotein, it is conceivable that it may bind at the $\mathrm{Ca}^{2+}$ sites on the $\mathrm{Zn}^{2+}$-saturated protein. Baudier \& Cole (1989) studied $\mathrm{Ca}^{2+}$ and $\mathrm{Tb}^{3+}$ (terbium ion) binding to $\mathrm{S}-100 \mathrm{~b}$. With apo-S-100b, $\mathrm{Tb}^{3+}$ initially went to the $\mathrm{Zn}^{2+}$ sites and bound to $\mathrm{Ca}^{2+}$ sites only when the $\mathrm{Zn}^{2+}$ sites were saturated. The binding of $\mathrm{Tb}^{3+}$ to $\mathrm{Ca}^{2+}$-binding sites was monitored by measuring the decrease in fluorescence intensity of $\mathrm{Zn}-\mathrm{S}-100 \mathrm{~b}$. By analogy, if $\mathrm{Cd}^{2+}$ were to bind to $\mathrm{Zn}-\mathrm{S}-100 \mathrm{~b}$ at the $\mathrm{Ca}^{2+}$-binding sites, then a decrease in $\mathrm{Zn}-\mathrm{S}-100 \mathrm{~b}$ fluorescence intensity could be anticipated. On the contrary, the relative fluorescence intensity of $\mathrm{Zn}-\mathrm{S}-100 \mathrm{~b}$ increased from 64.3 to 83.0 arbitrary units when $6 \times 10^{-5} \mathrm{M}-\mathrm{Cd}^{2+}$ was added (Table 1). To rule out the possibility that the affinity of $\mathrm{Cd}^{2+}$ for the $\mathrm{Ca}^{2+}$ sites on $\mathrm{Zn}-\mathrm{S}-100 \mathrm{~b}$ is very low, a titration of $\mathrm{Zn}-\mathrm{S}-100 \mathrm{~b}$ was carried out with $\mathrm{Cd}^{2+}$ to millimolar concentrations of $\mathrm{Cd}^{2+}$ (Fig. 3). Addition of $\mathrm{Cd}^{2+}$ to $\mathrm{Zn}-\mathrm{S}-100 \mathrm{~b}$ protein only resulted in an increase in fluorescence intensity, thereby giving no evidence for $\mathrm{Cd}^{2+}$ binding at the $\mathrm{Ca}^{2+}$ sites.

Another experimental parameter which is often used to probe the nature of metal-ion binding to $S-100 \mathrm{~b}$ is the use of the hydrophobic probe TNS. The apparent $K_{\mathrm{d}}$ value of $3 \times 10^{-5} \mathrm{M}$ obtained by titrations of TNS-labelled protein with $\mathrm{Cd}^{2+}$ compares well with the result obtained with the intrinsic fluorescence measurements. Experiments were designed to ascertain whether $\mathrm{Cd}^{2+}$ was mimicking the effects of either $\mathrm{Ca}^{2+}$ or $\mathrm{Zn}^{2+}$, and the results are summarized in Table 2. For instance, one may compare the effects of adding $\mathrm{Cd}^{2+}$ and $\mathrm{Ca}^{2+}$ to TNSlabelled $\mathrm{Zn}-\mathrm{S}-100 \mathrm{~b}$ protein. Addition to $\mathrm{Cd}^{2+}$ to $\mathrm{Zn}^{2+}$-loaded 


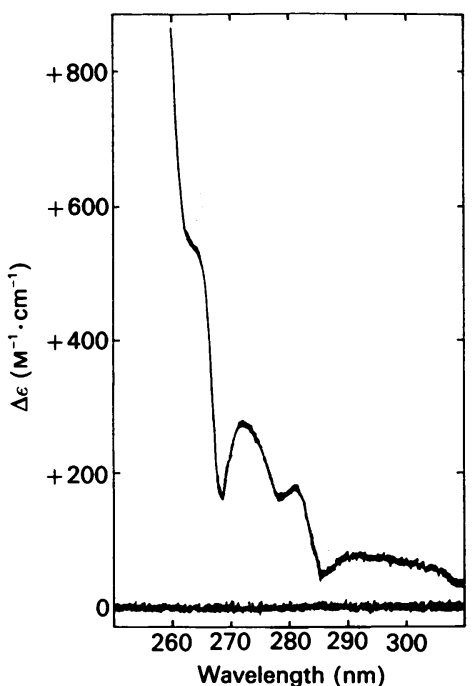

Fig. 4. U.v. difference spectrum of $5.1 \times 10^{-5} \mathrm{M}-\mathrm{S}-100 \mathrm{~b}$ in $0.1 \mathrm{M}$-Tris, pH 7.5, containing $9.9 \times 10^{-5} \mathrm{M}-\mathrm{Cd}^{2+}$

Results are expressed as differences in molar absorption, based on protein concentration.

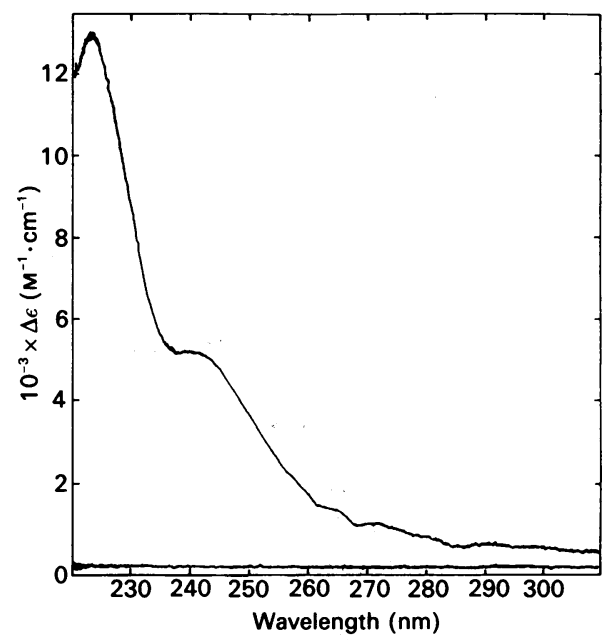

Fig. 5. U.v. difference spectrum of $9.9 \times 10^{-6} \mathrm{M}-\mathrm{S}-100 \mathrm{~b}$ in $0.1 \mathrm{M}$-Tris, pH 7.5, containing $5.5 \times 10^{-5} \mathrm{M}-\mathrm{Cd}^{2+}$

Results are expressed as differences in molar absorption, based on protein concentration.

labelled protein produced a $15 \%$ increase in TNS fluorescence intensity, whereas $\mathrm{Ca}^{2+}$ addition resulted in a $41 \%$ decrease in intensity. Clearly $\mathrm{Cd}^{2+}$ is not mimicking the effect of $\mathrm{Ca}^{2+}$ and presumably is not binding to the same sites. Also, addition of $\mathrm{Ca}^{2+}$ to $\mathrm{Cd}^{2+}$-saturated labelled protein induced a $50 \%$ increase in fluorescence intensity in contrast with a $41 \%$ decrease observed with $\mathrm{Zn}^{2+}$-labelled protein. Hence it would appear that $\mathrm{Cd}^{2+}$ is not bound to $\mathrm{S}-100 \mathrm{~b}$ in exactly the same manner as $\mathrm{Zn}^{2+}$.

To clarify the nature of the interaction of $\mathrm{Cd}^{2+}$ with $\mathrm{S}-100 \mathrm{~b}$, u.v. difference spectroscopy was employed. As with $\mathrm{Ca}^{2+}$ and $\mathrm{Zn}^{2+}$ ions, addition of $\mathrm{Cd}^{2+}$ to $\mathrm{S}-100 \mathrm{~b}$ produced a positive absorption (i.e. a red shift) in the $280 \mathrm{~nm}$ region, suggesting that the single tyrosine residue is moving to a more non-polar environment. The difference spectrum induced by $\mathrm{Cd}^{2+}$ at a lower S-100b protein concentration (Fig. 5) reveals the presence of positive bands below $250 \mathrm{~nm}$. There is a prominent shoulder at $240 \mathrm{~nm}$ and increasing absorbance at even lower wavelengths. Difference-spectral features, such as these have been observed

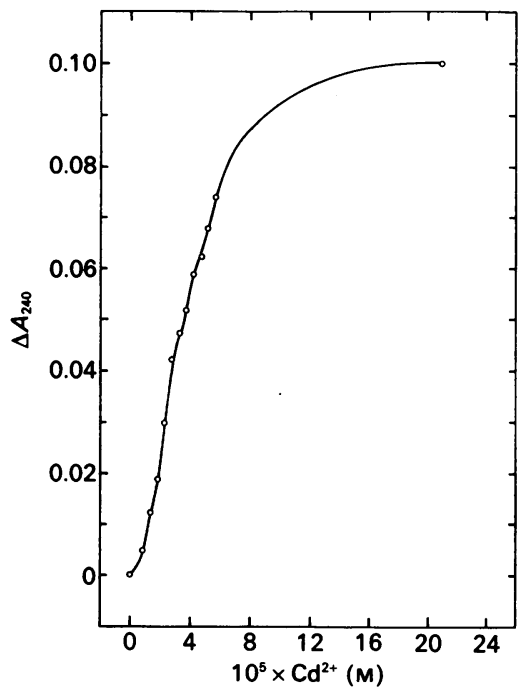

Fig. 6. Response of the differential absorbance at $240 \mathrm{~nm}$ of $\mathrm{S}-100 \mathrm{~b}$ in $0.1 \mathrm{M}$-Tris, $\mathrm{pH} 7.5$, to increasing $\mathrm{Cd}^{2+}$ concentration

before in cadmium-protein complexes, such as Cdmetallothionen (Vasak et al., 1981), horse liver alcohol dehydrogenas (Drum \& Vallee, 1970) and also in model complexes of $\mathrm{Cd}^{2+}$ with 2-mercaptoethanol (Vasak et al., 1981). In all these complexes, sulphur atoms are co-ordinated to $\mathrm{Cd}^{2+}$, and the observed bands have been assigned to charge-transfer transitions between thiolate and cadmium (Vasak et al., 1981). Hence it is reasonable to assign the $240 \mathrm{~nm}$-difference-spectral feature in $\mathrm{Cd}-\mathrm{S}-100 \mathrm{~b}$ to a $\mathrm{Cd} \rightarrow$ thiolate interaction. Competition experiments were carried out by adding either $\mathrm{Ca}^{2+}$ or $\mathrm{Zn}^{2+}$ to $\mathrm{Cd}^{2+}$-loaded protein and observing the difference absorbance at $240 \mathrm{~nm}$. Results obtained gave no evidence for either $\mathrm{Ca}^{2+}$ or $\mathrm{Zn}^{2+}$ competing with $\mathrm{Cd}^{2+}$ for binding at this site.

It is now possible to speculate on the sites of $\mathrm{Cd}^{2+}$ binding on the protein. Our spectral studies suggest that $\mathrm{Cd}^{2+}$ does not bind at the $\mathrm{Ca}^{2+}$-binding sites which are presumed to be the 'EFhand' region, i.e. residues 61-72 and the 'pseudo EF-hand' region, residues 18-31 (Szebenyi et al., 1981). For example, in the near- and far-u.v. c.d. studies the order of addition of $\mathrm{Ca}^{2+}$ and $\mathrm{Cd}^{2+}$ ions had no significant effect on the final c.d. spectrum, suggesting that the two metal ions bind at different sites. Also, the effect of $\mathrm{Ca}^{2+}$ and $\mathrm{Cd}^{2+}$ on the intrinsic fluorescence intensity of S-100b is different, again implying that the two metal ion bind at different sites. The $\beta$-chain has only two cysteine residues, $\mathrm{Cys}^{70}$ and $\mathrm{Cys}^{84}$, and since $\mathrm{Cys}^{70}$ is within the 'EF hand' $\mathrm{Ca}^{2+}$ binding site (Isobe \& Okuyama, 1981), it is unlikely to interact with $\mathrm{Cd}^{2+}$. Hence $\mathrm{Cd}^{2+}$ must be interacting with $\mathrm{Cys}^{84}$ on the $C$ terminal end of the $\beta$-chain, which presumably represents a unique $\mathrm{Cd}^{2+}$-binding site on the protein.

Of the two $\mathrm{Ca}^{2+}$-binding sites on the protein, at least one is common to both $\mathrm{Cd}^{2+}$ and $\mathrm{Zn}^{2+}$, since the perturbations induced in $\mathrm{S}-100 \mathrm{~b}$ protein fluorescence by $\mathrm{Cd}^{2+}$ and $\mathrm{Zn}^{2+}$ are very similar. Since S-100b has no tryptophan residues, the observed fluorescence must be due to $\mathrm{Tyr}^{17}$. Turner et al. (1989) have studied the effect of $\mathrm{Zn}^{2+}$ on the fluorescence decay and mean lifetimes of S-100b. Their results also suggest that $\mathrm{Zn}^{2+}$ binds in the $N$-terminal region of $\mathrm{S}-100 \mathrm{~b}$ and $\mathrm{Tyr}^{17}$. It is reasonable to assume that a metal-binding site near $\mathrm{Tyr}^{17}$, possibly involving either $\mathrm{His}^{15}$ or $\mathrm{His}^{25}$, when occupied by $\mathrm{Zn}^{2+}$ or $\mathrm{Cd}^{2+}$, results in the observed increase in protein fluorescence. In summary, then, out of the two $\mathrm{Cd}^{2+}$-binding sites on the $\beta$-chain, we believe one is located at the $N$-terminal region near $\operatorname{Tyr}^{17}$ and the other unique $\mathrm{Cd}^{2+}$-binding site is $\mathrm{Cys}^{84}$ located at the $C$-terminal end. 

31

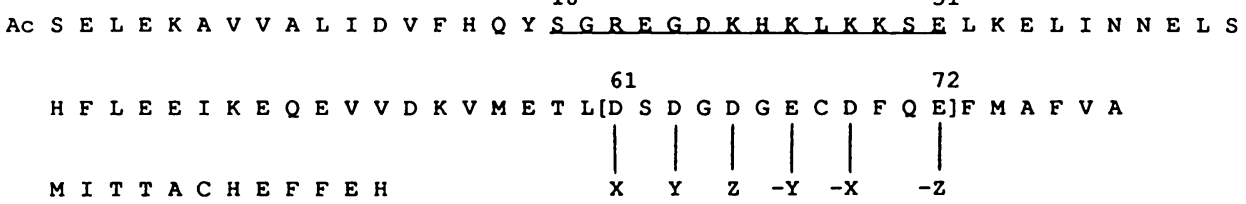

Fig. 7. Amino acid sequence of the $\beta$-subunit of bovine brain S-100b protein (Isobe $\&$ Okuyama, 1981)

The putative $\mathrm{Ca}^{2+}$-binding site is bracketed, with $\mathrm{X}, \mathrm{Y}, \mathrm{Z},-\mathrm{Y},-\mathrm{X}$ and $-\mathrm{Z}$ representing the ligands that co-ordinate the Ca ${ }^{2+}$ ion. $\mathrm{A}$ variant form of $\mathrm{Ca}^{2+}$-binding site similar to the I-II domain of bovine intestinal calcium-binding protein (Szebenyi et al., 1981) is found in the $N$-terminal region (underlined). Amino acid residues are identified by the single-letter notation. Ac refers to an acetyl group.

We are indebted to Mr K. Oikawa, Mr L. Hicks and Mr A. Keri for their expert technical assistance. This work was supported by the Medical Research Council of Canada and the Alberta Heart and Stroke Foundation.

\section{REFERENCES}

Anderson, A., Forsén, S., Thulin, E. \& Vogel, H. J. (1983) Biochemistry 22, 2309-2313

Armitage, I. M., Schoot-Uiterhamp, A. J. M., Chelbowski, J. F. \& Coleman, J. E. (1978) J. Mag. Reson. 29, 375-392

Bailey, D. V., Ellis, P. D. \& Fee, J. A. (1980) Biochemistry 19, 591-596

Baudier, J. \& Cole, D. J. (1989) Biochem. J. 264, 79-85

Baudier, J. \& Gérard, D. (1983) Biochemistry 22, 3360-3369

Baudier, J., Briving, C., Deinum, J., Haglid, K., Sorskog, L. \& Wallin, M. (1982) FEBS Lett. 161, 235-238

Baudier J., Glasser, N. \& Gérard, D. (1986) J. Biol. Chem. 261, 8192-8203

Bobsein, B. R. \& Myers, R. J. (1981) J. Biol. Chem. 256, 5313-5316

Donato, R. (1986) Cell Calcium 7, 123-145

Drum, D. E. \& Vallee, B. L. (1970) Biochem. Biophys. Res. Commun. 41, 33-39
Holmes, M. A. \& Matthews, B. W. (1981) Biochemistry 20, 6912-6920 Isobe, T. \& Okuyama, T. (1978) Eur. J. Biochem. 89, 379-388

Isobe, T. \& Okuyama, T. (1981) Eur. J. Biochem. 115, 469-474 Leung, I. K. M., Mani, R. S. \& Kay, C. M. (1986) Biochem. J. 237, 757-764

Mani, R. S. \& Kay, C. M. (1983a) Biochemistry 22, 3902-3907

Mani, R. S. \& Kay, C. M. (1983b) FEBS Lett. 163, 282-286

Mani, R. S. \& Kay, C. M. (1986) Biochem. J. 238, 715-719

Mani, R. S. \& Kay, C. M. (1987) Methods. Enzymol. 139, 168-187

Mani, R. S., Boyes, B. E. \& Kay, C. M. (1982) Biochemistry 21, 2607-2612

Mani, R. S., Shelling, J. G., Sykes, B. D. \& Kay, C. M. (1983) Biochemistry 22, 1734-1740

McClure, W. D. \& Edelman,. G. M. (1966) Biochemistry 5, 1908-1919

Szebenyi, D. M. F., Obendorf, S. K. \& Moffat, K. (1981) Nature (London) 294, 327-332

Turner, R. J., Roche, R. S., Mani, R. S. \& Kay, C. M. (1989) Biochem. Cell Biol. 67, 179-186

Vasak, M., Kagi, J. H. R. \& Hill, A. O. (1981) Biochemistry 20, 2852-2856

Vogel, H. J., Drakenberg, T., Forsén, S., O’Neil, J. D. \& Hoffman, T. (1985) Biochemistry 24, 3870-3876

Received 21 September 1990/19 November 1990; accepted 22 November 1991 